\title{
GLOBAL DERIVATIVES MARKET
}

\author{
Aleksandra Stankovska \\ European University - Republic of Macedonia, Skopje, email: aleksandra. \\ stankovska@eurm.edu.mk
}

DOI: 10.1515/seeur-2017-0006

\section{Abstract}

Globalization of financial markets led to the enormous growth of volume and diversification of financial transactions. Financial derivatives were the basic elements of this growth. Derivatives play a useful and important role in hedging and risk management, but they also pose several dangers to the stability of financial markets and thereby the overall economy. Derivatives are used to hedge and speculate the risk associated with commerce and finance.

When used to hedge risks, derivative instruments transfer the risks from the hedgers, who are unwilling to bear the risks, to parties better able or more willing to bear them. In this regard, derivatives help allocate risks efficiently between different individuals and groups in the economy. Investors can also use derivatives to speculate and to engage in arbitrage activity. Speculators are traders who want to take a position in the market; they are betting that the price of the underlying asset or commodity will move in a particular direction over the life of the contract.

In addition to risk management, derivatives play a very useful economic role in price discovery and arbitrage. Financial derivatives trading are based on leverage techniques, earning enormous profits with small amount of money.

Key words: financial derivatives, leverage, risk management, hedge, speculation, organized exchange, over- the counter market. 


\section{Introduction}

Derivatives are financial contracts that are designed to create market price exposure to changes in an underlying commodity, asset or event. In general they do not involve the exchange or transfer of principal or title (Randall, 2001). A derivative is defined by the BIS (1995) as "a contract whose value depends on the price of underlying assets, but which does not require any investment of principal in those assets". The global market for derivatives covers just about every asset in the world and there are even derivatives for hedging against the weather.

The innovation of financial derivatives and trading them on the financial market is of great significance, allowing adaptation of business entities in this new environment in the global economy. Derivative instruments balance business and financial transactions by reducing market risks associated with price oscillation, interest rates and exchange rates.

As a result of high profitability in the new field of trading and risk management in the area of derivative transactions, the main participants are the big financial and non-financial institutions in the role of hedgers, speculators and arbiters. By applying derivative instruments, we enable detection of price arbitrage, hedging and speculation, risk management, protection and betting on price changes in order to yield profit.

The globalization of investment flows encourages the growth of transactions on the financial derivatives market, the opening of new forward markets, the development of Over the Counter Market (OTC), the introduction of new types of financial derivatives and the development of new derivatives strategies. Derivatives are an important class of financial instruments that are central to today's financial and trade markets. They offer various types of risk protection and allow innovative investment strategies.

To deliver maximum benefits to its users and to the economy, the derivatives market must meet three prerequisites: derivatives trading and clearing must be safe, the market must be innovative and it must be efficient. Market participants, policy makers and regulators should support the providers in the derivatives market to ensure these prerequisites (Hull, 2012).

The derivatives market is, in a word, gigantic, often estimated at more than $\$ 1.2$ quadrillion. Some market analysts estimate the derivatives market at more than 10 times the size of the total world gross domestic product, or GDP. The reason the derivatives market is so large is because there are numerous derivatives available on virtually every possible type of investment asset, 
including equities, commodities, bonds and foreign currency exchange.

There is a degree of consensus today that financial innovation has a positive impact on the financial system on the whole. However, whenever a financial crisis arises - rather often in recent years - the debate on financial innovation is once again on the table, frequently focusing on the benefits and dangers of derivatives. The financial crisis that began in 2007 is of course no exception to the rule (Gunther, 2010). This was the case for the stock market crash of 1987 (Kleidon and Whaley, 1992) and for the Asian crisis (Dodd, 2002; Ghysels and Seon, 2005).

The stock market crash of October 1987 has, in part, been blamed on portfolio insurance strategies that used futures markets. Large losses associated with the use of derivatives by firms such as Procter \& Gamble (\$137 million), Metallgesellschaft ( $\$ 1$ billion), and Barings PLC ( $\$ 1.3$ billion), and by Orange County, California ( $\$ 1.7$ billion) have led to fear among some market participants that derivatives trading is a very risky activity that could lead to a widespread disruption of the financial system.

The growth of derivative transactions and the interconnections between major financial institutions around the world have led to concerns about the integrity of the global financial system. For example, derivatives allow additional leverage to be created in the financial system, and in times of financial turbulence, that leverage can precipitate a liquidity crisis, magnify market moves, and accelerate defaults. These systemic concerns have prompted new regulations, new procedures, and new disclosures to increase transparency. For example, the growth of hedge funds that make heavy use of derivatives has drawn the attention of regulators (Clarke, Silva and Thorley, 2013).

\section{Methodology}

To achieve the object of this paper, the derivative market data has been collected. At first, historical and comparative data are involved, as well as a full range of quantitative research methods. The secondary information is mostly from websites, books, journals, etc. Also, a lot of facts and date from domestic and foreign recent finance derivatives literature are taken into consideration.

\section{Literature review}

In the literature, much has been written about the financial derivatives. There have been few works on the role of derivatives in the international financial 
crises (Kregel, 1998; Dodd, 2000; Hermes, 2002; Dodd, 2002b; Dodd, 2003). The recent literature on the dangers of derivatives is more concerned by systemic risks. Several studies suggest that the sophistication of the products and the concentration of risks are potential sources of instability because of the increasing uncertainty, the repeated occurrence of extreme losses, and finally the greater possibility of global crisis. Among the solutions that have been proposed to mitigate risk, beyond strengthening internal control, putting clearinghouses into general use and limiting naked-transactions seem to be the most promising avenues (Gunther, 2010).

\section{Analysis and discussion}

\section{Derivatives markets}

Derivatives are an important class of financial instruments that are central to today's financial and trade markets. They offer various types of risk protection and allow innovative investment strategies. In the last 30 years, derivatives have become increasingly important in finance.

Derivatives markets are successful institutions because they make financial markets more efficient. This generally means that borrowing and lending can occur at lower cost than would otherwise be the case because derivatives reduce transaction costs.

Building blocks for derivatives markets (Fratzscher, 2006):

1. Product design:

- Economic rationale for hedging needs,

- Liquid cash market, long and short position,

- Market determined prices, interest/FX rates, and

- System stability, no moral hazard risks.

2. Regulation:

- Lead regulator, capital rules, reporting standards,

- Legal clarity: ISDA standards, enforceability,

- Accounting rules, transparency, disclosure, and

- Level playing field, tax harmonized, and integration.

3. Infrastructure:

- CCP, ISDA master, close - out netting,

- Demut. Exchanges, strong capital, margins,

- SRO rules enforced with limits, monitoring, and

- Certified investors, code of conduct. 
Benefits of derivatives make them indispensable to the global financial system and the economy:

- Derivatives provide risk protection with minimal upfront investment and capital consumption,

- Have very low total transaction costs compared to investing directly in the underlying asset,

- Can be tailored to the specific needs of any user,

- Allow investors to trade on future price expectations, and

- Allow fast product innovation because new contracts can be introduced rapidly.

The use of futures and option contracts also has some disadvantages (Clarke, Silva and Thorley, 2013):

- The need to understand complex relationships,

- Potential tracking error against the underlying security or index,

- Requirement of liquidity reserves to post and meet margin requirements,

- Daily settlement associated with marking to market, and

- Potential short-term tax consequences.

The explosive growth in derivative contracts occurred after 1999 when the Glass-Steagall Act was repealed, which allowed banks to operate as brokerage houses. Glass-Steagall, adopted in 1933, separated brokerage houses and banks in order to ensure banks would no longer be involved in risky transactions, which was the root cause of the crash that led to the Depression.

Today the size of derivatives markets is enormous, and by some measures it exceeds that for bank lending, securities and insurance. Estimates concerning the volume of the derivatives market range from 700 Trillion dollars to upwards of 1.5 Quadrillion dollars (including what is sometimes referred to as shadow derivatives). When investing becomes gambling, bad endings follow. The next credit crunch could make 2008-09 look mild by comparison. Bank of International Settlements (BIS) data show around \$700 trillion in global derivatives.

Along with credit default swaps and other exotic instruments, the total notional derivatives value is about $\$ 1.5$ quadrillion - about $20 \%$ more than in 2008, beyond what anyone can conceive, let alone control if unexpected turmoil strikes. The size of the economy is at about 70 to 75 Trillion dollars (annual World GDP).

Annual survey of derivatives exchange volumes highlights strong growth in the trading of futures and options at exchanges in China, India, Korea, 
Singapore and other parts of Asia (March, 2015). Another big theme in 2015 was a surge in the trading of commodity futures and options, which has grown more rapidly over the past several years than any other sector of the global listed derivatives markets.

At the global level, the total number of futures and options traded on exchanges worldwide rose to 24.78 billion contracts in 2015 . That was not quite a record, but it was up $13.5 \%$ from 2014, giving the industry its highest rate of growth since 2010 .

The statistic presents the world's leading derivative exchanges in 2015, by number of contracts traded and/or cleared. CME Group, incorporating Chicago Mercantile Exchange, Chicago Board of Trade and New York Mercantile Exchange, proved to be the largest derivatives exchange operator in 2015, with approximately 3.53 billion of contracts traded.

European exchanges also saw an increase in trading, with volume rising 8.2\% to 4.77 billion contracts. In contrast, North America pulled back slightly, with volume declining $0.2 \%$ to 8.19 billion contracts. Latin America, the fourth largest region, fell $4.4 \%$ to 1.45 billion, the third consecutive year of declining volume. And lastly, the group of countries in the "other" category, which consists of Turkey, Israel, South Africa and Greece, rose 51.9\% to 658.1 million contracts.

Table 1. Exchange-traded future, by location of exchange Notional principal, in billions of US dollars

\begin{tabular}{|c|c|c|c|c|c|c|c|}
\hline \multirow{2}{*}{$\begin{array}{l}\text { Instrument, location of ex- } \\
\text { change/market risk category/ } \\
\text { maturity }\end{array}$} & \multicolumn{2}{|c|}{ Open interest } & \multicolumn{5}{|c|}{ Daily average turnover } \\
\hline & $\begin{array}{l}\text { Dec } \\
2015\end{array}$ & $\begin{array}{l}\text { Mar } \\
2016\end{array}$ & $\begin{array}{l}\text { Nov } \\
2015\end{array}$ & $\begin{array}{l}\text { Dec } \\
2015\end{array}$ & \begin{tabular}{|l|} 
Jan \\
2016
\end{tabular} & $\begin{array}{l}\text { Feb } \\
2016\end{array}$ & $\begin{array}{l}\text { Mar } \\
2016\end{array}$ \\
\hline \multicolumn{8}{|l|}{ FUTURES } \\
\hline ALL MARKETS & 25,054 & 25,443 & 4,244 & 4,405 & 5,331 & 5,774 & 5,031 \\
\hline -Interest rate & 24,817 & 25,213 & 4,160 & 4,294 & 5,227 & 5,661 & 4,914 \\
\hline Short - term & 23,276 & 23,591 & 3,527 & 3,754 & 4,688 & 4,880 & 4,291 \\
\hline Long - term & 1,541 & 1,622 & 633 & 539 & 539 & 781 & 623 \\
\hline -Foreign exchange & 237 & 230 & 84 & 111 & 104 & 113 & 117 \\
\hline NORTH AMERICA & 15,644 & 15,784 & 2,690 & 2,966 & 3,716 & 4,035 & 3,449 \\
\hline - Interest rate & 15,501 & 15,653 & 2,629 & 2,884 & 3,644 & 3,956 & 3,367 \\
\hline Short - term & 14,648 & 14,767 & 2,270 & 2,665 & 3,370 & 3,478 & 3,104 \\
\hline
\end{tabular}




\begin{tabular}{|c|c|c|c|c|c|c|c|}
\hline Long - term & 853 & 886 & 359 & 220 & 274 & 478 & 263 \\
\hline - Foreign exchange & 143 & 130 & 61 & 82 & 72 & 79 & 82 \\
\hline EUROPE & 7,033 & 7,083 & 1,295 & 1,198 & 1,352 & 1,471 & 1,253 \\
\hline - Interest rate & 7,033 & 7,078 & 1,294 & 1,193 & 1,347 & 1,465 & 1,248 \\
\hline Short - term & 6,575 & 6,576 & 1.088 & 955 & 1,152 & 1,231 & 979 \\
\hline Long - term & 459 & 503 & 206 & 238 & 195 & 234 & 268 \\
\hline - Foreign exchange & 4 & 4 & 1 & 5 & 6 & 6 & 5 \\
\hline ASIA AND PACIFIC & 1,578 & 1,762 & 204 & 187 & 198 & 208 & 260 \\
\hline - Interest rate & 1,562 & 1,743 & 197 & 180 & 189 & 199 & 251 \\
\hline Short - term & 1,337 & 1,514 & 130 & 98 & 119 & 130 & 160 \\
\hline Long - term & 225 & 229 & 67 & 82 & 70 & 69 & 92 \\
\hline - Foreign exchange & 16 & 19 & 7 & 7 & 9 & 9 & 8 \\
\hline OTHER MARKETS & 795 & 814 & 55 & 54 & 64 & 60 & 69 \\
\hline - Interest rate & 720 & 738 & 40 & 36 & 47 & 41 & 48 \\
\hline Short - term & 716 & 734 & 40 & 36 & 47 & 41 & 48 \\
\hline Long - term & 4 & 4 & 0 & 0 & 0 & 0 & 0 \\
\hline - Foreign exchange & 75 & 75 & 15 & 18 & 17 & 19 & 22 \\
\hline
\end{tabular}

Source: http://www.bis.org/statistics/derstats.htm (Updated 4 May 2016).

One sector that did not share in the global upswing in trading volumes is the interest rate sector. Total trading of interest rate futures and options was 3.25 billion in 2015, about the same as the previous year and $13 \%$ below the peak of 3.74 billion set in 2007 , the last year before the financial crisis.

Table 2. Exchange-traded options, by location of exchange

Notional principal, in billions of US dollars

\begin{tabular}{|c|c|c|c|c|c|c|c|}
\hline \multirow{2}{*}{$\begin{array}{l}\text { Instrument, location of } \\
\text { exchange/market risk } \\
\text { category/maturity }\end{array}$} & \multicolumn{2}{|c|}{ Open interest } & \multicolumn{5}{|c|}{ Daily average turnover } \\
\hline & Dec 2015 & Mar 2016 & $\begin{array}{l}\text { Nov } \\
2015\end{array}$ & $\begin{array}{l}\text { Dec } \\
2015\end{array}$ & $\begin{array}{l}\text { Jan } \\
2016\end{array}$ & $\begin{array}{l}\text { Feb } \\
2016\end{array}$ & $\begin{array}{l}\text { Mar } \\
2016\end{array}$ \\
\hline \multicolumn{8}{|l|}{ OPTIONS } \\
\hline ALL MARKETS & 38,392 & 47,564 & 1,564 & 1,541 & 2,373 & 2,000 & 1,322 \\
\hline -Interest rate & 38,261 & 47,410 & 1,552 & 1,528 & 2,360 & 1,985 & 1,308 \\
\hline Short - term & 37,828 & 46,892 & 1,468 & 1,448 & 2,279 & 1,893 & 1,222 \\
\hline Long - term & 433 & 519 & 84 & 80 & 81 & 92 & 86 \\
\hline -Foreign exchange & 131 & 153 & 12 & 13 & 13 & 15 & 14 \\
\hline
\end{tabular}




\begin{tabular}{|c|c|c|c|c|c|c|c|}
\hline NORTH AMERICA & 26,735 & 35,621 & 1,044 & 1,169 & 1,924 & 1,502 & 1,062 \\
\hline - Interest rate & 26,669 & 35,538 & 1,036 & 1,161 & 1,915 & 1,491 & 1,053 \\
\hline Short - term & 26,413 & 35,210 & 990 & 1,114 & 1,861 & 1,427 & 1,004 \\
\hline Long - term & 256 & 328 & 46 & 47 & 54 & 63 & 50 \\
\hline - Foreign exchange & 66 & 83 & 8 & 9 & 9 & 11 & 9 \\
\hline EUROPE & 11,450 & 11,636 & 512 & 363 & 435 & 484 & 247 \\
\hline - Interest rate & 11,447 & 11,634 & 512 & 363 & 435 & 484 & 247 \\
\hline Short - term & 11,282 & 11,454 & 477 & 333 & 411 & 461 & 214 \\
\hline Long - term & 165 & 180 & 36 & 30 & 23 & 24 & 33 \\
\hline - Foreign exchange & 3 & 2 & 0 & 0 & 0 & 0 & 0 \\
\hline ASIA AND PACIFIC & 14 & 13 & 4 & 4 & 6 & 7 & 6 \\
\hline - Interest rate & 11 & 11 & 4 & 4 & 6 & 7 & 6 \\
\hline Short - term & - & 1 & - & - & - & 0 & - \\
\hline Long - term & 11 & 10 & 3 & 3 & 4 & 5 & 3 \\
\hline - Foreign exchange & 2 & 2 & 1 & 1 & 2 & 2 & 2 \\
\hline OTHER MARKETS & 194 & 294 & 3 & 4 & 9 & 7 & 8 \\
\hline - Interest rate & 134 & 227 & 1 & 1 & 6 & 5 & 5 \\
\hline Short - term & 133 & 227 & 1 & 1 & 6 & 5 & 5 \\
\hline Long - term & 0 & 0 & 0 & 0 & - & 0 & 0 \\
\hline - Foreign exchange & 60 & 66 & 2 & 2 & 2 & 2 & 3 \\
\hline
\end{tabular}

Source: http://www.bis.org/statistics/derstats.htm (Updated 4 May 2016).

The OTC segment accounts for 90 percent of the market in terms of notional amount outstanding. Here, the market volume is split equally between bilateral trading among market participants and multilateral trading, i.e. trading across a number of different market participants on organized marketplaces such as interdealer-brokers or electronic crossing networks. Exchange trading accounts for 10 percent of the market and is multilateral by definition. 
Table 3 Global OTC derivatives market

In billions of US dollars

\begin{tabular}{|l|l|l|l|l|l|l|l|l|}
\hline & \multicolumn{3}{|c|}{ Notional amounts outstanding } & \multicolumn{4}{c|}{ Gross market value } \\
\cline { 2 - 9 } & H1 & $\begin{array}{l}\mathrm{H} 2 \\
2014\end{array}$ & $\mathrm{H} 12015$ & $\begin{array}{l}\mathrm{H} 2 \\
2015\end{array}$ & $\begin{array}{l}\mathrm{H} 1 \\
2014\end{array}$ & $\begin{array}{l}\text { H2 } \\
2014\end{array}$ & $\begin{array}{l}\text { H1 } \\
2015\end{array}$ & $\begin{array}{l}\text { H2 } \\
2015\end{array}$ \\
\hline All contracts & 691,640 & 628,251 & 551,702 & 492,911 & 17,438 & 20,848 & 15,493 & 14,499 \\
\hline $\begin{array}{l}\text { Foreign } \\
\text { exchange } \\
\text { contracts }\end{array}$ & 74,782 & 75,043 & 73,607 & 70,446 & 1,724 & 2,936 & 2,539 & 2,579 \\
\hline $\begin{array}{l}\text { Interest rate } \\
\text { contracts }\end{array}$ & 563,290 & 505,431 & 434,492 & 384,025 & 13,461 & 15,586 & 11,062 & 10,148 \\
\hline $\begin{array}{l}\text { Equity-linked } \\
\text { contracts }\end{array}$ & 7,084 & 6,968 & 7,544 & 7,141 & 678 & 612 & 606 & 495 \\
\hline $\begin{array}{l}\text { Commodity } \\
\text { contracts }\end{array}$ & 2,206 & 1,869 & 1,671 & 1,320 & 269 & 318 & 237 & 297 \\
\hline $\begin{array}{l}\text { Credit de- } \\
\text { fault swaps }\end{array}$ & 19,462 & 16,399 & 14,594 & 12,294 & 635 & 593 & 453 & 421 \\
\hline Unallocated & 24,815 & 22,541 & 19,794 & 17,685 & 671 & 671 & 596 & 558 \\
\hline $\begin{array}{l}\text { Gross credit } \\
\text { exposure }\end{array}$ & & & & & 2,826 & 3,355 & 2,870 & 2,853 \\
\hline
\end{tabular}

Source: http://www.bis.org/statistics/derstats.htm (Updated 4 May 2016).

Approximately one-third (33\%) of the market's notional are cleared via central counterparties (CCPs), which consolidate and manage risks. Exchange-traded derivatives are always cleared centrally with CCPs, thus ensuring the full collateralization of open risk positions and guaranteeing the fulfillment of contracts. For OTC derivatives that are not CCP-cleared, risks are partially mitigated through bilateral collateralization, i.e. the pledging of assets to secure fulfillment of a transaction. A large share of derivatives exposure is currently not collateralized at all (approximately $32 \%$ ).

\section{Role of Derivatives in Causing the Global Financial Crisis}

Derivatives as the name implies are derived from the value of the underlying asset and hence are used to hedge against a rise or fall in the value of the underlying asset. Since derivatives essentially are traded on the basis of the value of the underlying asset, any disproportionate fall in the value of the underlying asset would cause a crash in the derivatives designed for that purpose. And this is what happened in the summer of 2007 when the housing market in the US started to go bust. Of course, the clever bankers had devised derivatives for such an eventuality as well and this was seen as an acceptable 
way of hedging risk. So, the obvious question is that if both sides of the risk have been hedged, then there should not have been a bust in the derivative market. The answer to this is that those investment banks and hedge funds that had found the right balance between the different hedging instruments survived the crash whereas the other banks like Lehmann that were highly leveraged because of their exposure to the subprime securities market collapsed. Some financial institutions have experienced large losses from the use of derivatives and other forms of leverage. For example, Barings Bank lost $\$ 1.4$ billion in 1994 and Société Générale lost $\$ 7$ billion in 2008. Nonetheless, losses would likely be greater if businesses did not use derivatives for hedging.

During the financial crisis in 2008, the root cause of the meltdown was derivatives. Specifically, CDOs, or Collateralized Debt Obligations related to mortgages and CDSs, or Credit Default Swaps. These derivatives represent bilateral insurance contracts between a protection buyer and a protection seller, covering a corporation's or sovereign's specific bond or loan. They typically last for five years, can be resold to another party, and are subject to counterparty risk - the risk that the protection seller will not be able to pay a claim.

Swaps are not standardized instruments and have been generally traded in over-the-counter markets - that is, directly between buyers and sellers rather than through a regulated exchange. An important aspect of CDSs is that an investor can purchase CDS protection without actually owning the insured security. In the period leading up to the financial crisis the advantageous leverage and convenience of CDSs fueled a speculative frenzy. Dealers on both the buy and sell sides rushed to issue and purchase CDSs written on debt they did not even own. While there are relatively safe CDSs based on interest rates or corporate bonds, some financial institutions wrote CDSs on low-quality subprime mortgage-backed securities (MBSs).

The absence of regulation played a major part in causing the crisis as the derivatives were traded in the OTC or the Over the Counter segment meaning that they were not subject to regulation. This meant that banks could play hard and fast with the rules and devise their own rules for derivative trading outside of the purview of the regulators.

\section{New Derivatives Regulatory Environment}

In order to minimize this systemic risk and to create a well-functioning market, both safety and integrity need to be ensured. As such, a blueprint that effectively reduces the systemic risk in the derivatives market should 
incorporate the following guidelines:

- Maximum use of derivatives trading on organized markets;

- $\quad$ Maximum use of central counterparties where trading on organized markets is not feasible;

- Bilateral collateralization of derivatives exposure when organized trading or the use of CCPs is not feasible;

- Mandatory registration of open risk positions and reporting standards for all derivative contracts.

Standardization of derivatives contracts and the respective processes is key to establishing safety and integrity in all areas of the derivatives market.

Examples of derivatives which are subject to new regulation under Title VII of the Dodd-Frank Act include interest rate, credit default and equity swaps, to name a few. Dodd-Frank's Title VII mandates regulators, including the Commodity Futures Trading Commission (CFTC) and the Securities and Exchange Commission (SEC), to undertake rulemakings designed to meet G20 objectives of increasing transparency and reducing systemic risk in the derivative markets, including:

- Reporting swap transactions to a swap data repository;

- Clearing sufficiently liquid and standardized swaps on central counterparties;

- Where appropriate, trading standardized swaps on trading platforms; and

- Setting higher capital and minimum margin requirements for uncleared swaps.

The CFTC has completed most of its Title VII mandated rulemakings, establishing a regime of regulatory oversight for many new entities, including swap intermediaries known as "Swap Dealers" and "Major Swap Participants" (MSPs), as wells as clearing houses and trading platforms. The SEC is also well underway in regards to its rulemaking and implementation of requirements covering security-based swaps (or "SBS").

According to Dodd-Frank, index CDS contracts must now be traded on swap execution facilities provided by companies such as Bloomberg and Tradeweb. One benefit of Dodd-Frank is that it brought the CDS market closer to an exchange-like format, allowing easier access to participants and letting them view bids and offers on an open, centralized screen. 
The Dodd-Frank Act established a broad, new regulatory regime, which stands to have profound effect on the market. New regulatory provisions will impact swap dealers, major swap participants, asset managers and other endusers, such as manufacturers, financial institutions, and agricultural concerns.

\section{Conclusion}

The derivatives market has grown rapidly in recent years as the benefits of using derivatives, such as effective risk mitigation and risk transfer, have become increasingly important. The derivatives market is huge - much bigger than the stock market when measured in terms of underlying assets. The value of the assets underlying outstanding derivatives transactions is several times the world gross domestic product. Competing for business, both derivatives exchanges and OTC providers, which by far account for the largest part of the market, have fueled growth by constant product and technology innovation. The statistics that are collected for the two markets are not exactly comparable, it is clear that the over-the-counter market is much larger than the exchangetraded market.

The derivatives market has recently attracted more attention against the backdrop of the financial crisis, fraud cases and the near failure of some market participants. Derivatives markets have come under a great deal of criticism because of their role in the credit crisis that started in 2007. Derivative products were created from portfolios of risky mortgages in the United States using a procedure known as securitization. Many of the products that were created became worthless when house prices declined. Financial institutions, and investors throughout the world, lost a huge amount of money and the world was plunged into the worst recession it had experienced for many generations.

The derivatives market has successfully developed under an effective regulatory regime. All three prerequisites for a well-functioning market - safety, efficiency and innovation - are fulfilled. While there is no need for structural changes in the framework under which OTC players and exchanges operate today, improvements are possible. Particularly in the OTC segment, increasing operating efficiency, market transparency and enhancing counterparty risk mitigation would help the global derivatives market to function even more effectively. 


\section{References:}

- Aksu, E., Camilleri, J. (2002). Democratizing Global Governance. Retrieved from Democratizing Global Governance. http://www.palgrave. com/us/book/9780333971222.

- John C. Hull. (2012). Options, Futures, and Other Derivatives. Retrieved from http://polymer.bu.edu/hes/rp-hull12.pdf.

- Oliver Fratzscher. (2006, March 23). Emerging Derivatives Markets in Asia. Retrieved from http://siteresources.worldbank.org/Extbanking/Resources/Derivative-Markets-Present.pdf.

- Robert W. Kolb, James A. Overdahl. (2010). Financial Derivatives: Pricing and Risk Management. New Jersey, USA: John Wiley \& Sons, Inc.

- Robert W. Kolb, James A. Overdahl. (2003). Financial Derivatives. New Jersy, USA: John Wiley \& Sons, Inc.

- Roger G. Clarke, Harindra de Silva, Steven Thorley. (2013). Fundamentals of Futures and Options. Retrieved from http://www.cfapubs.org/doi/ pdf/10.2470/rf.v2013.n3.1.

- Randall Dodd. (2004, May 10). Derivatives Markets: Sources of Vulnerability in U.S. Financial Markets. Retrieved from http://www.financialpolicy.org/fpfspr8.pdf.

- Will Acworth. (2016, March 15). Asia Takes The Lead. Retrieved from http://marketvoicemag.org/sites/default/files/pdf/March2016_TopStoryupd.pdf.

- The Global Derivatives Market A Blueprint for Market Safety and Integrity. Retrieve from https://deutsche boerse.com/blob/2534548/ebd7dc9b7aeac3efdf0c273309093130/data/the-global-derivatives-market-0909 de.pdf.

- http://www.bis.org/statistics/about_derivatives_stats.htm. 